\title{
HUMAN ALTERATION OF THE GLOBAL NITROGEN CYCLE: SOURCES AND CONSEQUENCES
}

\author{
Peter M. Vitousek, ${ }^{2}$ John D. Aber, ${ }^{3}$ Robert W. Howarth,${ }^{4}$ Gene E. Likens,${ }^{5}$ Pamela A. Matson, ${ }^{6}$ \\ David W. Schindler, ${ }^{7}$ William H. Schlesinger,${ }^{8}$ And David G. Tilman ${ }^{9}$ \\ ${ }^{2}$ Department of Biological Sciences, Stanford University, Stanford, California 94305 USA \\ ${ }^{3}$ Complex Systems Center, University of New Hampshire, Durham, New Hampshire 03824 USA \\ ${ }^{4}$ Section of Ecology and Systematics, Cornell University, Ithaca, New York 14850 USA \\ ${ }^{5}$ Institute of Ecosystem Studies, Mary Flagler Cary Arboretum, Millbrook, New York 12545 USA \\ ${ }^{6}$ Department of Environmental Science, Policy, and Management, University of California, Berkeley, California 94720 USA \\ ${ }^{7}$ Department of Biological Sciences, University of Alberta, Edmonton, Alberta Canada T6G $2 E 9$ \\ ${ }^{8}$ Department of Botany, Duke University, Durham, North Carolina 27709 USA \\ ${ }^{9}$ Department of Ecology, Evolution, and Behavior, University of Minnesota, Saint Paul, Minnesota 55108 USA
}

Abstract. Nitrogen is a key element controlling the species composition, diversity, dynamics, and functioning of many terrestrial, freshwater, and marine ecosystems. Many of the original plant species living in these ecosystems are adapted to, and function optimally in, soils and solutions with low levels of available nitrogen. The growth and dynamics of herbivore populations, and ultimately those of their predators, also are affected by N. Agriculture, combustion of fossil fuels, and other human activities have altered the global cycle of $\mathrm{N}$ substantially, generally increasing both the availability and the mobility of $\mathrm{N}$ over large regions of Earth. The mobility of $\mathrm{N}$ means that while most deliberate applications of $\mathrm{N}$ occur locally, their influence spreads regionally and even globally. Moreover, many of the mobile forms of $\mathrm{N}$ themselves have environmental consequences. Although most nitrogen inputs serve human needs such as agricultural production, their environmental consequences are serious and long term.

Based on our review of available scientific evidence, we are certain that human alterations of the nitrogen cycle have:

1) approximately doubled the rate of nitrogen input into the terrestrial nitrogen cycle, with these rates still increasing;

2) increased concentrations of the potent greenhouse gas $\mathrm{N}_{2} \mathrm{O}$ globally, and increased concentrations of other oxides of nitrogen that drive the formation of photochemical smog over large regions of Earth;

3) caused losses of soil nutrients, such as calcium and potassium, that are essential for the long-term maintenance of soil fertility;

4) contributed substantially to the acidification of soils, streams, and lakes in several regions; and

5) greatly increased the transfer of nitrogen through rivers to estuaries and coastal oceans.

In addition, based on our review of available scientific evidence we are confident that human alterations of the nitrogen cycle have:

6) increased the quantity of organic carbon stored within terrestrial ecosystems;

7) accelerated losses of biological diversity, especially losses of plants adapted to efficient use of nitrogen, and losses of the animals and microorganisms that depend on them; and

8) caused changes in the composition and functioning of estuarine and nearshore ecosystems, and contributed to long-term declines in coastal marine fisheries.

Manuscript received 1 November 1996. Reprints of this 14-page report are available for $\$ 2.25$ each. Prepayment is required. Order reprints from the Ecological Society of America, Attention: Reprint Department, 2010 Massachusetts Avenue, NW, Suite 400, Washington, D.C. 20036. 


$738 \quad$ PETER M. VITOUSEK ET AL. $\quad$ Ecological Applications 7, No. 3

Key words: agriculture and the global N cycle; anthropogenic global change; biological diversity and the nitrogen cycle; ecosystem functioning, control by $N$; eutrophication of estuaries; global $N$-cycle alteration, scientific consensus on; nitrogen-containing trace gases; nitrogen cycle, global; nitrogen deposition and nitrogen loss; nitrogen and land-water interactions.

\section{INTRODUCTION}

The productivity and dynamics of many unmanaged terrestrial and marine ecosystems, and most agricultural and managed-forestry ecosystems, are limited by the supply of biologically available nitrogen. Humans are altering the global cycle of $\mathrm{N}$ via combustion of fossil fuels, production of nitrogen fertilizers, cultivation of nitrogen-fixing legumes, and other actions (Galloway et al. 1995). Increased $\mathrm{N}$ availability increases productivity and biomass accumulation substantially, at least in the short-term (Vitousek and Howarth 1991). Consequently, changes in $\mathrm{N}$ can alter the global cycle of $\mathrm{C}$, affecting both the rate of increase of carbon dioxide in the atmosphere and the response of ecosystems to that increase (Schimel et al. 1995). Increasing $\mathrm{N}$ availability also generally reduces the biological diversity of affected ecosystems, and changes the rates and pathways of $\mathrm{N}$ cycling and loss (Tilman 1987, Berendse et al. 1993, Aber et al. 1995). Nitrate leaches through soils to stream water and groundwater, depleting soil minerals, acidifying soils, and altering downstream freshwater and coastal marine ecosystems (Likens et al. 1996, Nixon et al 1996); reactive oxides of $\mathrm{N}$ are important precursors of both acid rain and photochemical smog, and can be transported hundreds of kilometers to downwind ecosystems (Chameides et al. 1994); long-lived nitrous oxide contributes to anthropogenic enhancement of the greenhouse effect (Albritton et al. 1995). This report reviews and summarizes the extent of human alteration of the $\mathrm{N}$ cycle, and consequences for the functioning of terrestrial, freshwater, and marine ecosystems. It is not an exhaustive compilation of such studies-that would require volumes. Rather, it presents an overview of the current state of scientific understanding of this human-caused global change.

\section{Human Alteration of the Global N Cycle}

The cycle of $\mathrm{N}$ is unique in that it consists of a massive, well-mixed, and (to most organisms) wholly unavailable pool of nitrogen gas $\left(\mathrm{N}_{2}\right)$ in the atmosphere; a relatively small and almost wholly biologically mediated conversion of $\mathrm{N}_{2}$ to chemical forms of $\mathrm{N}$ that are available to most organisms; and a pool of $\mathrm{N}$ that cycles among plants, animals, microorganisms, soils, solutions, and sediments, and between land, water, and the atmosphere (Delwiche 1970). The most fundamental human-caused change to the global $\mathrm{N}$ cycle is a doubling of the transfer from the vast and unreactive atmospheric pool to biologically available forms on land (termed " $\mathrm{N}$ fixation").

As with any other human-caused global change, it is necessary to evaluate the state of the $\mathrm{N}$ cycle prior to extensive human alteration, as well as the magnitude of current human effects upon the cycle. And as with many global changes, determining the background state of the $\mathrm{N}$ cycle is difficult. Two natural processes transfer $\mathrm{N}$ from $\mathrm{N}_{2}$ to biologically available forms-lightning and biological $\mathrm{N}$ fixation. The latter is carried out by microorganisms, many of them in symbiotic relationships with higher plants (especially legumes) and algae. In analyzing the global $\mathrm{N}$ cycle, the standard unit of measure is the teragram $\left(10^{12} \mathrm{~g}\right.$, abbreviated $\mathrm{Tg}$ ), or million $\left(10^{6}\right)$ metric tons of N. Lightning fixes $<10 \mathrm{Tg}$ N/yr now (Galloway et al 1995), and it has not been affected by human activity. Estimates of biological $\mathrm{N}$ fixation in marine ecosystems are variable and uncertain, ranging from $<30 \mathrm{Tg} / \mathrm{yr}$ to $>300 \mathrm{Tg} / \mathrm{yr}$ (Carpenter and Capone 1983, Carpenter and Romans 1991, Galloway et al 1995). Estimates of nitrogen fixation in terrestial ecosystems are better constrained; prior to extensive human activity, organisms probably fixed between 90 and $140 \mathrm{Tg}$ N/yr (Soderlund and Rosswall 1982, Paul and Clark 1989, Schlesinger 1991). Several recent reviews demonstrate that human activity clearly has enhanced rates of $\mathrm{N}$ fixation on land substantially (Fig. 1) (Smil 1990, 1991, Vitousek and Matson 1993, Ayers et al 1994, Galloway et al 1995). A number of pathways are involved, including industrial fixation of $\mathrm{N}_{2}$ for use as fertilizer, cultivation of crops with the capacity to fix $\mathrm{N}$ symbiotically, and mobilization and fixation during fossil-fuel combustion.

\section{Sources of change}

$N$ fertilizer.-Current industrial fixation of $\mathrm{N}$ for use as fertilizer totals $\approx 80 \mathrm{Tg} / \mathrm{yr}$ (FAO 1993). This figure does not include manures and other organic $\mathrm{N}$ fertilizers; globally, these account for more $\mathrm{N}$ than does industrial fertilizer, but manure application represents recycling of already-fixed $\mathrm{N}$ rather than new fixation. Industrial $\mathrm{N}$ fixation has increased exponentially from near zero in the 1940s. Until the late 1970s, most industrial $\mathrm{N}$ fertilizer was applied in developed countries, but use there has stabilized while applications in developing countries have increased dramatically. The immediacy and rapidity of the recent increase in $\mathrm{N}$ fixation is difficult to overstate. For example, Kates et al. (1990) point out more than half of all the industrially fixed $\mathrm{N}$ applied in human history up to 1990 had been used since 1980 (Fig. 2). The momentum of human population growth and increasing urbanization ensure that industrial $\mathrm{N}$ fixation will continue at high rates for decades.

Fossil fuel combustion.-The burning of fossil fuels 


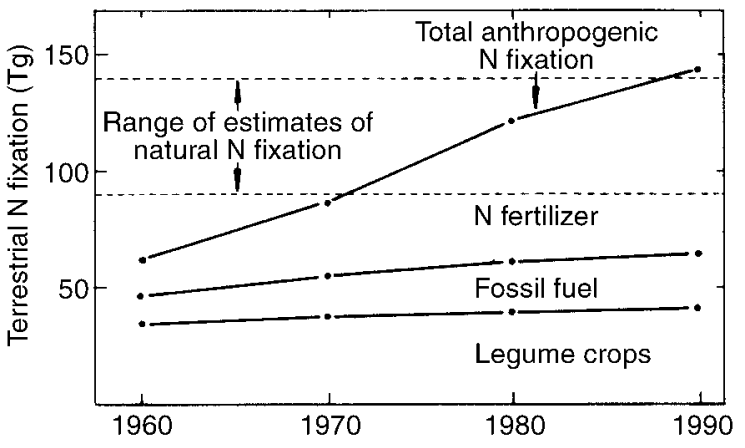

FIG. 1. Anthropogenic fixation of $\mathrm{N}$ in terrestrial ecosystems over time, in comparison with the range of estimates of natural biological $\mathrm{N}$ fixation on land. Modified from Galloway et al. (1995: Fig. 5).

transfers fixed $\mathrm{N}$ from long-term geological reservoirs to the atmosphere, and high-temperature combustion fixes a small amount of atmospheric $\mathrm{N}_{2}$. A total of $>20$ $\mathrm{Tg} / \mathrm{yr}$ of fixed $\mathrm{N}$ is emitted to the atmosphere during fossil-fuel combustion.

Nitrogen-fixing crops.-Leguminous crops and forages (i.e., soybeans, peas, alfalfa) support symbiotic $\mathrm{N}$-fixing microorganisms, and thereby derive much of their $\mathrm{N}$ directly from atmospheric $\mathrm{N}_{2}$. Fixation of $\mathrm{N}$ in excess of background rates in the natural communities that legume crops have replaced represents new, anthropogenic $\mathrm{N}$ fixation. There is also substantial biological $\mathrm{N}$ fixation associated with cultivation of some non-legumes, notably rice. The quantity of $\mathrm{N}$ fixed by crops is more difficult to determine than is industrial $\mathrm{N}$ fixation; Galloway et al. (1995) estimate it at 32-53 $\mathrm{Tg} / \mathrm{yr}$, and we will use $40 \mathrm{Tg} / \mathrm{yr}$ as an estimate here.

Mobilization of N.- - In addition to enhancing fixation, human activity liberates $\mathrm{N}$ from long-term biological storage pools, and thereby contributes further to increasing the biological availability of $\mathrm{N}$. The major pathways of mobilization are discussed in Vitousek and Matson (1993); they include biomass burning, which volatilizes $>40 \mathrm{Tg} / \mathrm{yr}$ of $\mathrm{N}$, with $\approx 20 \mathrm{Tg} / \mathrm{yr}$ of that fixed N (Lobert et al. 1990, Andreae 1993); land clearing and conversion, which could mobilize $20 \mathrm{Tg} / \mathrm{yr}$; and the drainage of wetlands and consequent oxidation of their organic soils, which could mobilize $10 \mathrm{Tg} / \mathrm{yr}$ or more (Armentano 1980). Moreover, the loss of wetlands removes a significant sink for fixed nitrogen (denitrification, the conversion of nitrate to $\mathrm{N}_{2}$ under anaerobic conditions), further increasing the mobility of $\mathrm{N}$ to and through streams and rivers (Leonardson 1994). All of these pathways have substantial uncertainties in both the quantity of $\mathrm{N}$ mobilized and its fate, but together they could contribute significantly to increasing the biological availability of $\mathrm{N}$.

Overall, human activity causes the fixation of $\approx 140$ $\mathrm{Tg}$ of new $\mathrm{N}$ per year in terrestrial ecosystems (Fig. 1) - at the upper end of the range of estimates for total background $\mathrm{N}$ fixation on land-and mobilizes perhaps
$70 \mathrm{Tg}$ more. It is fair to conclude that human activity has doubled (or more) the transfer of $\mathrm{N}$ from the atmosphere to biologically available pools on land. The added $\mathrm{N}$ is spread unevenly over Earth's surface-some areas (e.g., northern Europe) are profoundly altered (Berendse et al. 1993, Wright and van Breeman 1995), while others (e.g., remote south-temperate regions) receive little direct input (Galloway et al. 1982, Hedin et al. 1995)—but no place on Earth is unaffected. The recent increase in the quantity of fixed $\mathrm{N}$ in circulation is readily detectable in cores from the glacial ice of Greenland (Mayewski et al. 1986).

\section{Effects on the Atmosphere}

The modern increase in fixation and mobilization of nitrogen is associated with increased emission, transport, reaction, and deposition of trace nitrogen gases, including nitrous oxide $\left(\mathrm{N}_{2} \mathrm{O}\right)$, nitric oxide $(\mathrm{NO})$, and ammonia $\left(\mathrm{NH}_{3}\right)$. Some human activities affect the atmosphere directly; for example, essentially all of the $>20 \mathrm{Tg}$ of $\mathrm{N}$ fixed or mobilized during fossil-fuel combustion and other high-temperature processes is emitted to the atmosphere as NO. Human activities also increase emissions indirectly. For example, agricultural fertilization increases the concentration of volatile $\mathrm{NH}_{3}$ in soils, increases microbial processing of fixed $\mathrm{N}$, and ultimately increases emissions of nitrogen gases from soils and groundwater (Eichner 1990, Schlesinger and Hartley 1992). Similarly, inadvertent N fertilization of unmanaged ecosystems downwind of agricultural/industrial areas can increase gas emissions from their soils.

These anthropogenic changes in the nitrogen cycle drive regional and global changes in the atmosphere. Nitrous oxide is increasing at the rate of $0.2-0.3 \% / y r$, with most of the change occurring recently (Prinn et al. 1990). Nitrous oxide is a very effective greenhouse

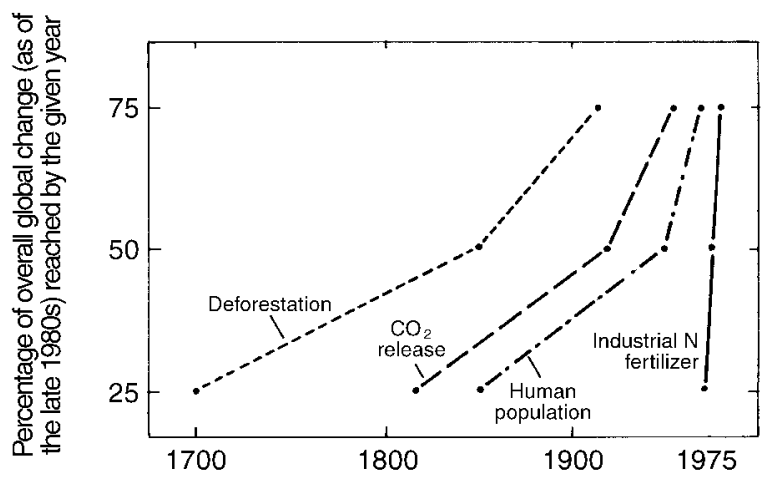

FIG. 2. Comparative timing of a number of global changes. Considering the extent of change as of the late 1980s as $100 \%$, the figure shows the year by which $25 \%, 50 \%$, and $75 \%$ of the overall change in deforestation, $\mathrm{CO}_{2}$ release to the atmosphere, human population growth, and application of industrial fertilizer $\mathrm{N}$ had occurred. Revised from Kates et al. (1990:Fig. 1.1). 


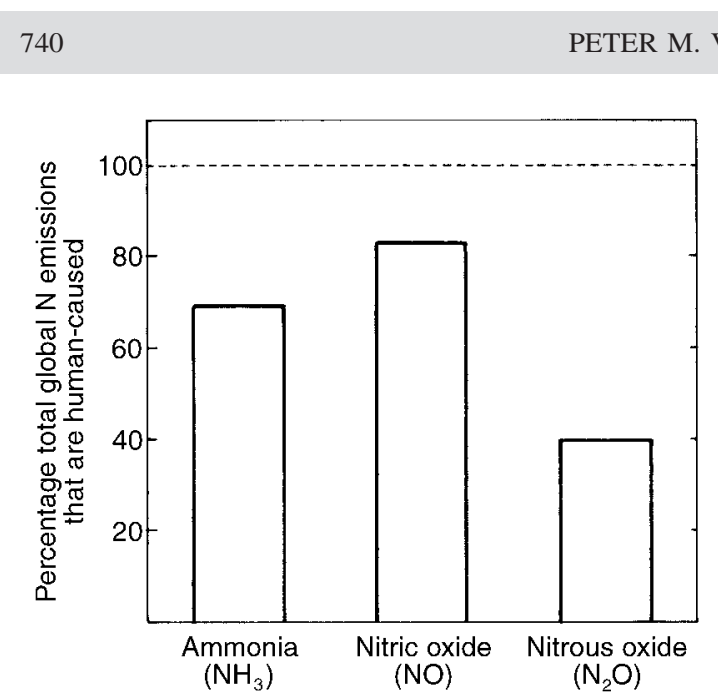

FIG. 3. The anthropogenic contribution to the total emissions of nitrogen-containing trace gases. Ammonia data are from Schlesinger and Hartley (1992), nitric oxide from Delmas et al. (in press), and nitrous oxide from Prather et al. (1995).

gas that absorbs infrared radiation in spectral windows not covered by other gases; it contributes a few percent to overall greenhouse warming (Albritton et al. 1995). It is unreactive in the troposphere, but it is destroyed by photolysis or by reaction with excited oxygen atoms in the stratosphere, where it can catalyze the destruction of stratospheric ozone (Crutzen and Ehhalt 1977). While the increasing concentration of $\mathrm{N}_{2} \mathrm{O}$ is clearly documented, the sources of that increase remain a matter of some discussion. Both fossil-fuel combustion and direct consequences of agricultural fertilization have been considered and rejected as the major source; there is a developing consensus that many anthropogenic sources (fertilizers, N-enriched groundwater, N-saturated forests, biomass burning, land clearing, nylon manufacture) all contribute to the increase (Prather et al. 1995). This "dispersed source" view is consistent with a terrestrial $\mathrm{N}$ cycle that has been systematically enriched by anthropogenic $\mathrm{N}$ fixation (Fig. 1).

In contrast to $\mathrm{N}_{2} \mathrm{O}, \mathrm{NO}$ and $\mathrm{NH}_{3}$ are highly reactive in the atmosphere, and changes in their concentrations must be evaluated on local, regional, or subcontinental scales. Nitric oxide plays several critical roles in atmospheric chemistry. It affects the concentration of the main oxidizing agent in the atmosphere, the hydroxyl $(\mathrm{OH})$ radical (Logan 1985). Moreover, it contributes (often in a rate-limiting way) to the photochemical formation of tropospheric ozone $\left(\mathrm{O}_{3}\right)$, the most important atmospheric gaseous pollutant in terms of its effects on human health and plant productivity (Reich and Amundson 1985, Chameides et al. 1994). When NO concentrations are high, the oxidation of carbon monoxide ( $\mathrm{CO})$, non-methane hydrocarbons, and methane $\left(\mathrm{CH}_{4}\right)$ leads to a net production of tropospheric ozone (Jacob and Wofsy 1990, Williams et al 1992); when NO concentrations are low, oxidation of these com- pounds is a sink for ozone. Finally, the end product of NO oxidation, nitric acid, is a principal component of acid rain. As with $\mathrm{N}_{2} \mathrm{O}$, a number of sources contribute to NO emissions, including microbial activity in fertilized soils. However, combustion is the dominant source; fossil fuel combustion emits $>20 \mathrm{Tg} / \mathrm{yr}$, and biomass burning (now mostly human-caused) may add about $8 \mathrm{Tg} / \mathrm{yr}$ more (Levy et al. 1991). Global NO emissions from soils total 5-20 Tg/yr (Yienger and Levy 1994, Davidson 1991) and a substantial fraction of this $\mathrm{N}$ is anthropogenic. Overall, $80 \%$ or more of all NO emissions globally are human-caused (Fig. 3; Delmas et al., in press).

Ammonia $\left(\mathrm{NH}_{3}\right)$ is the primary acid-neutralizing agent in the atmosphere, where it influences the $\mathrm{pH}$ of aerosols, cloudwater, and rainfall. As with $\mathrm{NO}, \mathrm{NH}_{3}$ emissions from ecosystems, transport in the atmosphere, and return to ecosystems via gas absorption, dry deposition, or in solution represent important pathways of nitrogen movement between ecosystems. Numerous studies have demonstrated substantial volatilization of fertilizer $\mathrm{N}$ as $\mathrm{NH}_{3}$ (Fenn and Hossner 1985, Denmead 1990); Schlesinger and Hartley (1992) estimate $\mathrm{NH}_{3}-\mathrm{N}$ fluxes from fertilized fields at $10 \mathrm{Tg} / \mathrm{yr}$. Emissions from domestic animal wastes (32 Tg/yr) and biomass burning ( $5 \mathrm{Tg} / \mathrm{yr}$ ) are also important globally; in sum, anthropogenic sources account for nearly $70 \%$ of all global ammonia emissions (Schlesinger and Hartley 1992; Fig. 3).

Enhanced emissions of $\mathrm{N}$ to the atmosphere have led to enhanced deposition of $\mathrm{N}$ on land and in the oceans. Based on extensive measurements of precipitation in remote areas of the southern hemisphere, where anthropogenic deposition of $\mathrm{N}$ is minimal, annual wet deposition of inorganic $\mathrm{N}$ in unpolluted regions averages $0.1-0.7 \mathrm{~kg} \mathrm{~N} / \mathrm{ha}$, of which $40 \%$ is nitrate and $60 \%$ is ammonium (Galloway et al. 1982, 1996, Likens et al. 1987). These fluxes are $<10 \%$ of rates of wet deposition in the human-altered midwestern and eastern United States and $<1 \%$ of rates in the most heavily affected areas of northern Europe (Berendse et al. 1993, Wright and Van Breeman 1995).

\section{EFFECTS ON TERRESTRIAL ECOSYSTEMS $N$ enrichment and the C cycle}

It is clear that rates of plant production and of the accumulation of biomass in whole ecosystems are limited by N supply over much of Earth's surface (Tamm 1991, Vitousek and Howarth 1991), particularly in temperate and boreal regions, and equally clear that human activity has increased $\mathrm{N}$ deposition substantially over much of this area. How much $\mathrm{C}$ is stored within terrestrial ecosystems as a consequence of anthropogenic $\mathrm{N}$ fixation and deposition? This question has important implications for the global cycle of $\mathrm{C}$, in that deposition of anthropogenic fixed $\mathrm{N}$ could help to explain the "missing sink," the imbalance between known $\mathrm{CO}_{2}$ 
emissions from fossil fuel combustion and deforestation vs. known $\mathrm{CO}_{2}$ accumulation in the atmosphere (Schimel et al. 1995).

Experimental work at European and American sites indicates that a large portion of the nitrogen retained by forest, wetland, and tundra ecosystems stimulates carbon uptake and storage (e.g., Rasmussen et al. 1993, Aber et al. 1995). Nitrogen deposition can also stimulate decomposition in some forests (Boxman et al. 1995), but the effects of added $\mathrm{N}$ in stimulating production are generally quantitatively more important (Hunt et al. 1988, Berg and Tamm 1991).

A number of analyses have calculated how much terrestrial $\mathrm{C}$ storage could result from $\mathrm{N}$ deposition (Peterson and Melillo 1985, Schindler and Bayley 1993, Hudson et al. 1994, Townsend et al. 1996); estimates of net $\mathrm{C}$ storage range from 0.1 to $1.3 \mathrm{Pg} \mathrm{C} / \mathrm{yr}$ $(1 \mathrm{Pg}=1000 \mathrm{Tg})$. The magnitude of potential C storage has tended to increase in more recent analyses, as the magnitude of change in the global $\mathrm{N}$ cycle is better appreciated (Keeling et al. 1996). The most recent analysis of the global $\mathrm{C}$ cycle by the Intergovernmental Panel on Climate Change (IPCC) concluded that $\mathrm{N}$ deposition could represent a major component of the missing C sink (Schimel et al. 1995). Further refinements could come from more complete analyses of the fraction of anthropogenic $N$ that is retained within terrestrial ecosystems, on regional to continental scales (Galloway et al. 1995, Howarth et al. 1996).

\section{Nitrogen saturation and ecosystem function}

Ultimately, there are declining returns in the response of plant production and carbon storage to additions of $\mathrm{N}$, and consequently the potential for ecosystems to retain added $\mathrm{N}$ through increased production and organic matter storage is limited. The term "nitrogen saturation" (Ågren and Bosatta 1988, Aber et al. 1989, Aber 1992) has been applied to changes in $\mathrm{N}$ cycling in forest ecosystems that occur as $\mathrm{N}$ limitations to biological functions are relieved by $\mathrm{N}$ additions. In a fully $\mathrm{N}$-saturated system (particularly one that is not storing $\mathrm{C}$ for some other reason such as its stage of stand development, or increasing $\mathrm{CO}_{2}$ ), $\mathrm{N}$ losses to streams, groundwater, and the atmosphere should approach total $\mathrm{N}$ deposition, and any fertilization effects or continued $\mathrm{C}$ storage should disappear.

Concerns regarding the effects of $\mathrm{N}$ deposition on forest health and downstream ecosystems arose following observation of significant increases in nitrate concentrations in some lakes and streams (Grennfelt and Hultberg 1986, Henriksen and Brakke 1988, Stoddard 1994), and documented declines and mortality in coniferous evergreen forests in Europe (Schulze 1989). These observations have led to several field experiments that examined interactions between $\mathrm{N}$ deposition and forest ecosystem function (e.g., Van Miegrot et al. 1992, Kahl et al. 1993, Wright and van Breeman 1995,
Magill et al. 1997). These experiments showed that where increased $\mathrm{N}$ additions led to increased nitrate mobility, the nitrate losses also led to losses of nutrient cations and increases in soil and water acidity (McNulty and Aber 1993, Boxman et al. 1995, Emmett et al. 1995).

Excess $\mathrm{N}$ availability also can cause nutrient imbalances in trees. These are expressed as root or foliar element ratios, especially $\mathrm{Ca}: \mathrm{Al}$ and $\mathrm{Mg}: \mathrm{N}$ ratios. As described below, $\mathrm{Ca}$ and $\mathrm{Mg}$ are lost via leaching, while the availability of $\mathrm{Al}$ is enhanced by acidity. Such imbalances may be linked to reductions in net photosynthesis, photosynthetic N-use efficiency, forest growth, and even increased tree mortality (Shortle and Smith 1988, Schulze 1989, Aber et al. 1995, Cronan and Grigal 1995).

In the northeastern United States, large shifts in foliar element ratios and increases in nitrate-leaching losses are generally restricted to high-elevation sites (which receive greater $\mathrm{N}$ deposition), those with shallow soils, those which have received little human disturbance (which presumably were close to input-output balance prior to receiving enhanced $\mathrm{N}$ deposition), and those receiving experimental additions of $\mathrm{N}$ well above ambient levels (e.g., Driscoll et al. 1987, Murdoch and Stoddard 1991, Kahl et al. 1993). In contrast, forests that have been subjected to intense or repeated biomass removals have very high capacities to retain $\mathrm{N}$ (Aber et al. 1995, Magill et al. 1997). The early stages of $\mathrm{N}$ saturation have also been noted in response to elevated $\mathrm{N}$ deposition in dry conifer forests surrounding the Los Angeles Basin, California (Bytnerowicz and Fenn 1996), in the Front Range of the Colorado Rockies (Baron et al. 1994), and in forests in which symbiotic $\mathrm{N}$-fixing organisms are major components (Van Miegroet 1992). Nitrogen saturation is much further advanced over extensive areas of northern Europe, where rates of anthropogenic $\mathrm{N}$ deposition are several-fold greater than the most extreme areas in North America (Berendse et al. 1993).

Overall, the ability of a forest ecosystem to retain $\mathrm{N}$ is linked to its productive potential, and the degree to which previous disturbances have resulted in $\mathrm{N}$ removal and current $\mathrm{N}$ limitations. Thus, the extent and importance of $\mathrm{N}$ saturation are tightly linked to changes in land use, climate, atmospheric $\mathrm{CO}_{2}$ and $\mathrm{O}_{3}$, and other environmental variables that are also subject to rapid change.

\section{Nitrogen deposition and changes in ecosystem composition and biodiversity}

The addition of limiting nutrients can dramatically change which species are dominant in ecosystems and markedly decrease the overall biodiversity of ecosystems. For example, experimental additions of nitrogen to grassland ecosystems in England have led to increased dominance by a few nitrogen-demanding grass 
species, and to suppression of many other plant species (Lawes and Gilbert 1880, Brenchley and Warington 1958, Thurston 1969, Silvertown 1980). The highest rate of $\mathrm{N}$ loading caused the number of plant species to decline more than five-fold. Similarly dramatic reductions in plant diversity have been observed following $\mathrm{N}$ loading in North American grasslands (Tilman 1987, 1996, Huenneke et al. 1990), European grasslands (Bobbink et al. 1988), and European heathlands (Aerts and Berendse 1988).

Because of its high population density and interweaving of intensive livestock operations and industry, rates of $\mathrm{N}$ deposition in the Netherlands are the highest in the world, averaging 4-9 $\mathrm{g} \cdot \mathrm{m}^{-2} \cdot \mathrm{yr}^{-1}$. The consequences of that enhanced deposition are well documented. Nitrogen deposition causes the conversion of heathlands to species-poor grasslands and forest (Aerts and Berendse 1988). Because heathlands occur on sandy, nitrogen-poor soils, the effect of deposition is to make heathlands more similar in composition to plant communities that occupy more fertile soils. Thus, biological diversity at the landscape level is reduced by $\mathrm{N}$ deposition, just as species richness within communities is reduced.

The loss of diversity caused by $\mathrm{N}$ deposition (or other global changes) can affect other aspects of ecosystem function. For example, recent experiments in the Midwestern United States showed that productivity in species-poor ecosystems that result from nitrogen addition was much less stable when they experienced a major drought (Tilman and Downing 1994). Similarly, the most diverse plots experienced much less year-to-year variation in productivity in response to climatic variation during non-drought years than did the most species-poor plots (Tilman 1996).

\section{Effects on Aquatic Systems}

\section{Historical changes in water chemistry}

Given human-caused acceleration of $\mathrm{N}$ fixation and other changes in $\mathrm{N}$ cycling, it is no surprise that $\mathrm{N}$ concentrations have increased over time in surface waters. In more-developed regions, nitrate concentrations have been more-or-less continuously measured in many rivers and other drinking-water supplies for decades. Analysis of these data show that nitrate has more than doubled in the Mississippi River since 1965 (Turner and Rabalais 1991, Justic et al. 1995), and that nitrate concentrations in major rivers in the northeastern U.S. have increased by 3 - to 10 -fold since the early 1900 s (N. Jaworski and R. W. Howarth, unpublished manuscript) Available evidence suggests similar trends for many European rivers since the turn of the century (Paces 1982, Larsson et al. 1985), and Henriksen and Brakke (1988) report a doubling of nitrate in 1000 Norwegian lakes in less than a decade. Moreover, nitrate fluxes and concentrations in the large rivers of the world are correlated with human population densities
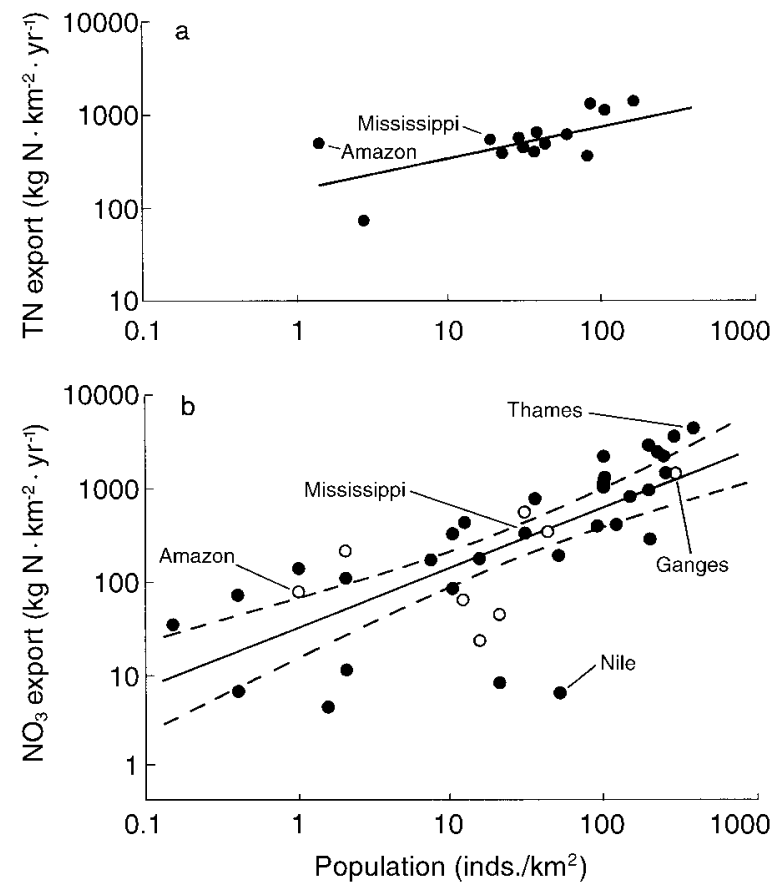

FIG. 4. Export of total nitrogen (a) and nitrate (b) from river systems, as a function of human population density in the watershed. Reprinted from Howarth et al. (1996:Fig. 3a, b) with permission of Kluwer Academic Publishers (where Fig. 3b was modified from Peierls et al. [1991]). Note logarithmic scale.

in the watersheds (Peierls et al. 1991, Cole et al. 1993) (Fig. 4).

No comparable historical data on the concentrations of total dissolved $\mathrm{N}$ in surface waters are available. Analyses of recent data suggest that $\mathrm{N}$ in streams and rivers draining relatively undisturbed forests is largely organic N (Schindler et al. 1980, Hedin et al. 1995); with increasing human disturbance, total $\mathrm{N}$ fluxes in rivers increase and a higher proportion is composed of nitrate (Howarth et al 1996). Total $N$ fluxes in rivers also are correlated with human population density, but the slope is much shallower for total $\mathrm{N}$ than $\mathrm{NO}_{3}$, illustrating the greater mobility of nitrate relative to other forms of $\mathrm{N}$ (Howarth et al 1996).

Fluxes of total $\mathrm{N}$ in temperate-zone rivers surrounding the North Atlantic Ocean are highly correlated with net anthropogenic inputs of $\mathrm{N}$ to their watersheds (Fig. $5 ; r^{2}=0.73, P=0.002$; Howarth et al. 1996). Net anthropogenic $\mathrm{N}$ inputs are defined as the sum of inputs as fertilizer, through $\mathrm{N}$ fixation by agricultural crops, as deposition of oxidized $\mathrm{N}$ from the atmosphere, and as the net import or export of $\mathrm{N}$ in food and feedstocks (see also Jordan and Weller 1996). For this regional analysis, $\mathrm{N}$ from sewage, $\mathrm{N}$ from animal feedlots, and $\mathrm{NH}_{4}$ deposition from the atmosphere were considered to represent recycling of nitrogen within regions. For most of the regions surrounding the North Atlantic, anthropogenic inputs of $\mathrm{N}$ are dominated by fertilizer, 


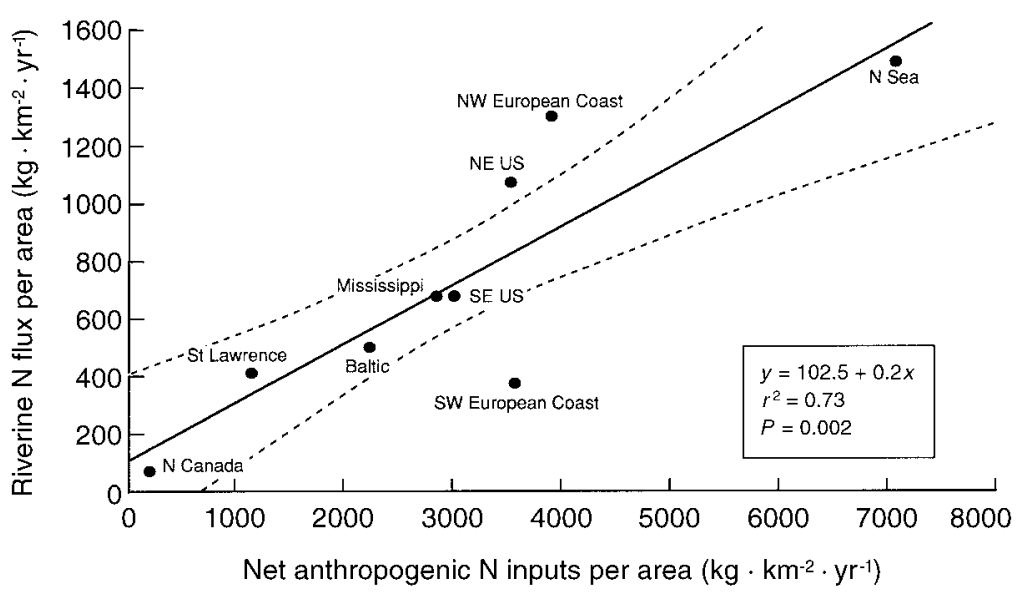

FIG. 5. Export of total nitrogen from watersheds surrounding the North Atlantic Ocean, as a function of net anthropogenic inputs of nitrogen to their watersheds. Net anthropogenic inputs are defined as (industrial $\mathrm{N}$ fertilizer $+\mathrm{N}$ fixation by legume crops + atmospheric inputs of oxidized $\mathrm{N}+$ net imports of $\mathrm{N}$ in food and feedstock). Reprinted from Howarth et al. (1996: Fig. 5a) with permission of Kluwer Academic Publishers.

but for the northeastern United States and the Saint Lawrence River and Great Lakes basin, atmospheric deposition of oxidized nitrogen is the greatest input (Fisher and Oppenheimer 1991, Howarth et al. 1996). Even though fertilizer inputs dominate in most regions, overall $\mathrm{N}$ exports from the regions are better correlated with atmospheric deposition of oxidized $\mathrm{N}$.

Using relatively undisturbed areas as references, Howarth et al. (1996) estimated that riverine total N fluxes from most of the temperate regions surrounding the North Atlantic Ocean may have increased from preindustrial times by 2 - to 20 -fold. For the North Sea region, the $\mathrm{N}$ increase may have been 6 - to 20 -fold. Increased concentrations of nitrate have also been observed in groundwater in many agricultural regions (Moody 1990). The magnitude of this storage is difficult to determine, outside of a few well-characterized aquifers. Overall, the annual increment of $\mathrm{N}$ added to groundwater probably represents a small fraction of the increased nitrate transported in surface waters (Howarth et al. 1996), but the long residence time of groundwater in many aquifers means that decreases in groundwater quality are likely to continue as long as human effects on the $\mathrm{N}$ cycle are substantial.

Nitrate in drinking water represents a human health concern-when levels are high, microorganisms in the stomach may convert nitrate to nitrite. Nitrite absorbed into the bloodstream converts hemoglobin to methemoglobin, which is ineffective in oxygen transport in the blood. Acute and chronic elevated methemoglobin can kill infants, in a condition known as methemoglobinemia (Lee 1970). Although the disease is rare in the U.S., the potential for methemoglobinemia exists whenever nitrate levels exceed $10 \mathrm{mg}$ N/L-the U.S. Public Health Service standard.

\section{Nitrogen and acidification}

The interaction between nitrogen deposition and freshwater acidification is complex. In many areas, re- cent reductions in $\mathrm{SO}_{2}$ emissions have reduced inputs of sulfuric acid to ecosystems, while emissions of the nitrogen oxides that are precursors of nitric acid have gone unchecked. As a result of this shift, and the fact that many catchments in moderate- to high-deposition areas appear to be becoming nitrogen saturated, nitric acid is playing an increasing role in lake acidification. In addition, nitric acid is highly mobile in snowpacks subjected to periodic melting, and in many areas it is the predominant strong acid in the spring acid pulse (Schaefer et al. 1990).

Nitrogen contributes to acidity in two ways-nitric acid does so directly, and ammonium deposited to terrestrial and aquatic systems can be a further source of acidity, in that both biological uptake of ammonium and nitrification produce hydrogen ions (Schindler et al. 1985, Schuurkes and Mosello 1988, Johnson et al. 1991). Moreover, where human alteration of the $\mathrm{N}$ cycle induces nitrate loss, the nitrate is a mobile anion that can move through soils to streams and groundwater, pulling cations with it and thereby depleting the soil of calcium and other nutrients (Likens et al. 1970, 1996). As calcium is depleted the leaching of toxic inorganic aluminum is increased. In $\mathrm{N}$-saturated areas of Europe, a substantial fraction of atmospheric nitrate moves through terrestrial ecosystems without ever being taken up by organisms (Durka et al. 1994). The effects of acidity, and of the mobilization of aluminum that it causes, on aquatic systems have been reviewed by Irving (1990) and others. In areas without much acid-neutralizing capacity, they are clear and profound. The crucial point is that recent increases in the fixation and emission of $\mathrm{N}$, and the increasing extent of N-saturated ecosystems, mean that controlling emissions of compounds that produce sulfuric acid will be insufficient to decrease acid rain or its effects on streams and lakes (Posch et al. 1995). The importance of $\mathrm{N}$ in acid- 
ifying ecosystems is clearly recognized in Europe, where intergovernmental efforts are underway to reduce $\mathrm{N}$ emissions and deposition on a regional basis (DoE 1994). Critical loads (threshold levels) for nitrogen are considered to be an important part of managing acid precipitation there (Nilsson and Grennfelt 1988), and wetlands and riparian areas are being restored in an attempt to prevent excess nitrogen from entering freshwater and coastal zones (Leonardson 1994). An approach based on critical loads may not be appropriate conceptually for some of the consequences of $\mathrm{N}$ deposition-it is not clear there are thresholds for all of these effects-but critical loads may nonetheless represent a useful tool for managing $\mathrm{N}$ deposition.

Acidification itself can also disrupt the nitrogen cycle in freshwater ecosystems. In experimental lakes in Ontario, nitrification of ammonium ceased at $\mathrm{pH}$ values below 5.6 (Rudd et al. 1988), while higher nitrate inputs stimulated aquatic denitrification (Rudd et al. 1990). Nitrogen fixation in Little Rock Lake ceased at $\mathrm{pH}<5$, but no effect on nitrification was observed (Schindler et al. 1991).

In freshwater ecosystems with sufficient phosphorus, additions of inorganic nitrogen can cause eutrophication; this can occur either independently or coupled to acidification (Schindler et al. 1985). Decreased diversity of both animal and plant species generally accompanies both eutrophication and acidification (Schindler 1990, 1994).

\section{Fertilization and eutrophication in estuaries and coastal seas}

The eutrophication of estuaries and coastal seas is one of the best-documented and best-understood consequences of human-altered N cycling (Howarth 1988, NRC 1993, Justic et al. 1995, Nixon 1995, Nixon et al. 1996); it represents perhaps the greatest threat to the integrity of coastal ecosystems (NRC 1993, 1994). In most temperate-zone estuaries and coastal seas, net primary production and eutrophication are controlled by nitrogen inputs (Fig. 6; Boynton et al. 1982, D’Elia et al. 1986, Howarth et al. 1995, Nixon et al. 1996). Some areas are controlled by $\mathrm{P}$ rather than $\mathrm{N}$, particularly tropical lagoons where adsorption onto carbonate sands provides a major sink for phosphate, and in some temperate estuaries and seas that receive extremely high loading of N (Howarth et al. 1995). Most often, however, eutrophication is caused by anthropogenic $\mathrm{N}$ loading - in sharp contrast to the majority of lakes in the temperate zone, where phosphorus is the element most limiting net primary production and controlling eutrophication (Schindler 1977).

Eutrophication has substantial effects on ecosystem function and composition in estuaries. It can cause anoxia (no oxygen) or hypoxia (low oxygen) in stratified waters, and both anoxia and hypoxia appear to be becoming more prevalent in many estuaries and coastal

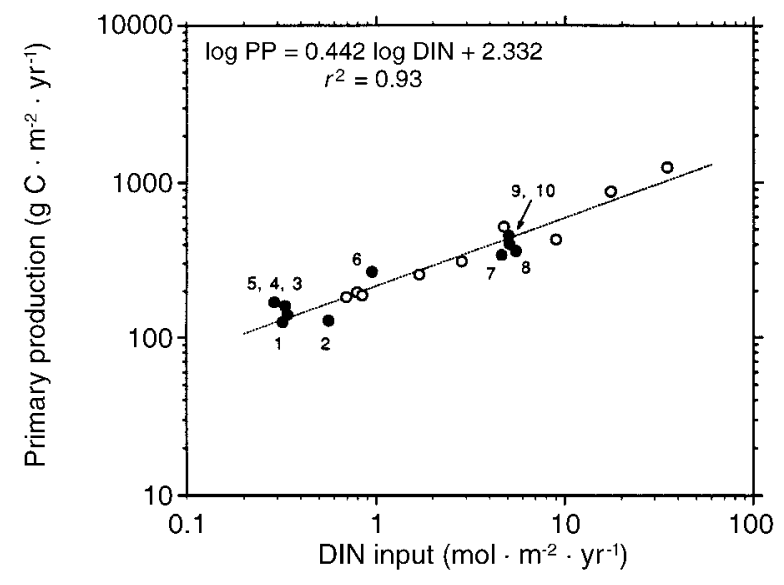

FIG. 6. Primary production (PP) by phytoplankton $\left({ }^{14} \mathrm{C}\right.$ uptake) as a function of the estimated rate of input of dissolved inorganic nitrogen (DIN) per unit area in a variety of marine ecosystems. Natural systems are represented by solid circles; open circles are for large $\left(13 \mathrm{~m}^{3}, 5 \mathrm{~m}\right.$ deep), wellmixed mesocosm tanks at the Marine Ecosystems Research Laboratory during a multi-year fertilization experiment. Reprinted from Nixon et al. (1996:Fig. 5) with permission of Kluwer Academic Publishers.

seas (NRC 1993). There is good evidence for increasing anoxia since the 1950 s or 1960 s for the Baltic Sea (Larsson et al. 1985), the Black Sea (Lein and Ivanov 1992), and Chesapeake Bay (Officer et al. 1984). Hypoxic events have increased in Long Island Sound (Parker and O'Reilly 1991), the North Sea (Rosenberg 1985), and the Kattegat (Baden et al. 1990); lowoxygen problems have resulted in significant losses of fish and shellfish resources (Baden et al. 1990, Hansson and Rudstam 1990, NRC 1993).

Eutrophication is also associated with a loss of diversity, both in the benthic community and among planktonic organisms (Howarth 1991). Among phytoplankton, this can be manifested by dominance of nuisance algae. An increased incidence of nuisance algal blooms has been observed in many estuaries and coastal seas, and although the reasons are not completely known, compelling evidence suggests that increased nutrient supplies are responsible at least in part (Smayda 1989, NRC 1993). Toxic blooms of dinoflagellates (Anderson 1989, Burkholder et al. 1992) and of browntide organisms (Cosper et al. 1987) during the 1980s were responsible for extensive mortality of fish and shellfish in many estuaries. Eutrophication can also lead to a loss of diversity in subtidal beds of macroalgae, in seagrass beds, and in corals (NRC 1993).

\section{MAJOR UnCERTAINTIES}

This analysis has focused on describing the scientific consensus on global change in the $\mathrm{N}$ cycle-in other words, what is known, and how we know it. There are also major uncertainties in our knowledge of the $\mathrm{N}$ cycle and how it relates to other aspects of global 
change; we highlight a few of the most fundamental ones here. It is always possible, and often valuable, to improve estimates of a regional or global process; here, however, we focus on important processes that are known so poorly as to make it difficult to detect anthropogenic global change, or to predict its consequences.

\section{Marine $N$ fixation}

Credible estimates of the rate of $\mathrm{N}$ fixation in marine ecosystems range over more than a factor of 10 (Galloway et al. 1995); as a consequence, the state of scientific understanding of both current and background $\mathrm{N}$ fixation in the ocean is insufficient to evaluate the extent or global significance of any human-caused global change in marine $\mathrm{N}$ fixation. There is some evidence that human alteration of the $\mathrm{N}$ cycle could alter biological processes in the open ocean (Knap et al. 1986, Cornell et al. 1995, Michaels et al. 1996), but it is difficult to evaluate this possibility given our lack of understanding of the unmodified $\mathrm{N}$ cycle in the open oceans.

\section{Changing resource limitation}

One consequence of human alteration of the global $\mathrm{N}$ cycle is that many ecosystems in which biological processes once were limited by $\mathrm{N}$ supply now receive large inputs of nitrogen, causing limitation by other resources to become more important. The dominant species in these systems may have evolved with nitrogen limitation; the ways they grow and function, and their symbiotic partners, could be highly tuned to it. How is the performance of organisms and ecosystems affected by shifts in resource limitation to conditions with which they have no evolutionary background, and to which they are not adapted?

\section{Nitrogen retention capacity}

There is substantial variation in the capacity of forest ecosystems and wetlands to retain added N. A number of interacting factors that correlate with a system's capacity to retain $\mathrm{N}$ (prior to becoming $\mathrm{N}$ saturated) have been identified, including the $\mathrm{C}: \mathrm{N}$ ratio of soil organic matter, soil texture and degree of chemical weathering, fire history, rate of biomass accumulation, and past human land use. Connections between ecosystems within landscapes can also affect losses of $\mathrm{N}$ to aquatic systems and the atmosphere. However, we lack a fundamental understanding of how and why the processes that retain $\mathrm{N}$ vary among systems, and how they have changed and will change with time.

\section{Background $N$ deposition and loss}

While information on current rates of $\mathrm{N}$ deposition and loss in developed regions is improving steadily, our understanding of these fluxes prior to extensive human effects is still patchy. In part, this reflects the fact that all of Earth is more or less affected by human activity. Nevertheless, studies in remote southern hemisphere temperate regions (Galloway et al. 1982, Hedin et al. 1995) illustrate that valuable information on areas that have been minimally altered by humans remains to be gathered.

\section{Alteration of denitrification}

At the scale of large river basins, the majority of nitrogen inputs to a region probably are denitrified (Howarth et al. 1996). Our understanding of the locus of this denitrification is inadequate, although it is clear that riparian areas and wetlands make important contributions. Human activity has influenced the quantity and distribution of denitrification-enhancing it by adding nitrate to ecosystems, by building dams, and by cultivating rice; decreasing it by draining wetlands and altering riparian areas-but these changes remain poorly characterized.

\section{Future Prospects and Management Options}

Globally, most of the anthropogenic enhancement of $\mathrm{N}$ fixation is closely tied to human activities related to food production. Intensive agricultural systems require large quantities of fixed $\mathrm{N}$; humanity requires intensive agriculture to support our growing (and urbanizing) population; and our population is likely to double (or more) by the end of the next century. Moreover, N fertilizer is a relatively inexpensive commodity, and a decision to apply fertilizer is often the least expensive and most effective option to increase agricultural yield. The production and application of $\mathrm{N}$ has grown exponentially, and the highest rates of application are found in some developing countries with the highest rates of population growth (Matthews 1994). Galloway et al. (1994) suggest that by 2020 the global production of nitrogen fertilizer will increase to $134 \mathrm{Tg} \mathrm{N} / \mathrm{yr}$, from a current level of about $80 \mathrm{Tg} \mathrm{N} / \mathrm{yr}$. Clearly, curtailing anthropogenic fixation of $\mathrm{N}$ will be a very difficult challenge.

Nevertheless, there are prospects for slowing growth in the amount of $\mathrm{N}$ fixed for agriculture, and for reducing the mobility (and hence consequences) of the $\mathrm{N}$ that is applied. While the use of fixed $\mathrm{N}$ in agriculture cannot be substituted, there are reasons to believe that the efficiency of $\mathrm{N}$ fertilizer can be increased substantially. A relatively large fraction of applied $\mathrm{N}$ (often half or more) is typically lost from agricultural systems as $\mathrm{N}_{2}$, trace gases, and nitrate; from a local viewpoint this is an expensive waste, while from a broader perspective it is a significant driver of global change. A number of management practices that can increase the efficiency of fertilizer $\mathrm{N}$ have been recognized. To the extent that these can be developed, improved, and implemented widely, some human fixation of $\mathrm{N}$ can be foregone. For example, Matson et al. (1996) evaluated $\mathrm{N}$ trace-gas flux in two commercial sugar cane plan- 
tations in Hawaii. One applied $\mathrm{N}$ in several split applications, with increasing quantities of $\mathrm{N}$ timed to the requirements of the growing crop. Fertilizer was dissolved in irrigation water, which was delivered under the soil surface. The other plantation used fewer, larger applications of fertilizer $\mathrm{N}$ broadcast onto the soil surface. The more knowledge-intensive system used $2 / 3$ as much $\mathrm{N}$ per crop as the more fertilizer-intensive system, and losses of $\mathrm{N}_{2} \mathrm{O}$ and $\mathrm{NO}$ (and probably other forms of $\mathrm{N}$ as well) were 10-fold less than from the fertilizer-intensive system. Moreover, the knowledgeintensive system yielded more and was more profitable; applying more knowledge proved cheaper than applying more fertilizer. The development and spread of this and similar technologies should be a high priority for ecologists as well as agronomists; they provide the opportunity to reduce costs and slow the rate of global change. The transfer of N-efficient technologies to developing regions is particularly crucial.

There are also ways that nitrogen lost from fertilized farmland can be prevented from reaching water courses, where it contributes to eutrophication. Such actions may be particularly important in areas adjacent to estuaries and other nitrogen-limited waters. For example, many streams have been channelized and wetlands drained to increase the area of agricultural land. We now realize that the elimination of wetlands and riparian areas has also eliminated important natural nitrogen traps, where much of the entering nitrate is denitrified. Restoration of such areas and the construction of artificial wetlands have been shown to be effective at reducing the transfer of nitrogen from agricultural land to the Baltic (Jansson et al. 1994 and other papers in Ambio 23, number 6).

The other major source of a human-fixed $\mathrm{N}$ is fossilfuel combustion, which will also increase markedly, especially in the developing world, as we enter the next century. Galloway et al. (1994) suggest that the production of $\mathrm{NO}_{x}$ from fossil fuels will be $\approx 46 \mathrm{TgN} / \mathrm{yr}$ in 2020, roughly double the current rate of emission. Improvements in the efficiency of fuel combustion and in the interception of its airborne byproducts must be implemented to reduce these emissions; again, it will be particularly important to transfer efficient technologies to developing economies.

\section{ACKNOWLEDGMENTS}

We thank the Pew Charitable Trusts for financial support provided through a Pew Scholars Fellowship to David Tilman; we thank Steve Carpenter, Judy Meyer, and Lou Pitelka for thoughtful comments on the manuscript; and we thank Cheryl Nakashima and Nancy Larson for manuscript preparation.

\section{Literature Cited}

Aber, J. D. 1992. Nitrogen cycling and nitrogen saturation in temperate forest ecosystems. Trends in Ecology and Evolution 7:220-223.

Aber, J. D., A. Magill, S. G. McNulty, R. D. Boone, K. J. Nadelhoffer, M. Downs, and R. Hallett. 1995. Forest bio- geochemistry and primary production altered by nitrogen saturation. Water Air and Soil Pollution 85:1665-1670.

Aber, J. D., K. J. Nadelhoffer, P. Steudler, and J. M. Melillo. 1989. Nitrogen saturation in northern forest ecosystems. BioScience 39:378-386.

Aerts, R., and F. Berendse. 1988. The effect of increased nutrient availability on vegetation dynamics in wet heathlands. Vegetatio 76:63-69.

Ågren, G. I., and E. Bosatta. 1988. Nitrogen saturation of terrestrial ecosystems. Environmental Pollution 54:185197.

Albritton, D. L., R. G. Derwent, I. S. A. Isaksen, M. Lal, and D. J. Wuebbles. 1995. Trace gas radiative forcing indices. Pages 209-231 in J. T. Houghton, L. G. Meira Filho, J. Bruce, H. Lee, B. A. Callander, E. Haites, N. Harris, and K. Maskell, editors. Climate change 1994: radiative forcing of climate change. Cambridge University Press, Cambridge, England.

Anderson, D. M. 1989. Toxic algal blooms and red tides: a global perspective. Pages 11-16 in T. Okaichi, D. M. Anderson, and T. Nemoto, editors. Redtides: biology, environmental science, and toxicology. Elsevier, New York, New York, USA.

Andreae, M. O. 1993. The influence of tropical biomass burning on climate and the atmospheric environment. Pages 113-150 in R. S. Oremland, editor. Biogeochemistry of global change: radiatively active trace gases. Chapman \& Hall, New York, New York, USA.

Armentano, T. V. 1990. Drainage of organic soils as a factor in the world carbon cycle. BioScience 30:825-830.

Ayers, R. U., W. H. Schlesinger, and R. H. Socolow. 1994. Human impacts on the carbon and nitrogen cycles. Pages 121-155 in R. H. Socolow, C. Andrews, R. Berkhout, and V. Thomas, editors. Industrial ecology and global change. Cambridge University Press, New York, New York, USA.

Baden, S. P., L. O. Loo, L. Pihl, and R. Rosenberg. 1990. Effects of eutrophication on benthic communities including fish: Swedish west coast. Ambio 19:113-122.

Baron, J. S., D. S. Ojima, E. A. Holland, and W. J. Parton. 1994. Analysis of nitrogen saturation potential in a Rocky Mountain tundra and forest: implications for aquatic ecosystems. Biogeochemistry 27:61-82.

Berendse, F., R. Aerts, and R. Bobbink. 1993. Atmospheric nitrogen deposition and its impact on terrestrial ecosystems. Pages 104-121 in C. C. Vos and P. Opdam, editors. Landscape ecology of a stressed environment. Chapman \& Hall, London, England.

Berg, B., and C. O. Tamm. 1991. Decomposition and nutrient dynamics of litter in long-term optimum nutrition experiments. I. Organic matter decomposition in Picea abies needle litter. Scandinavian Journal of Forest Research 6:305321.

Bobbink, R., L. Bik, and J. H. Willems. 1988. Effects of nitrogen fertilization on vegetation structure and dominance of Brachypodium pinnatum (L.) Beauv. in chalk grassland. Acta Botanica Neerlandica 37:231-242.

Boxman, A. W., D. van Dam, H. F. G. van Dyck, R. F. Hogervorst and C. J. Koopmans. 1995. Ecosystem responses to reduced nitrogen and sulphur inputs into two coniferous forest stands in the Netherlands. Forest Ecology and Management 71:7-30.

Boynton, W. R., W. M. Kemp, and C. W. Keefe. 1982. A comparative analysis of nutrients and other factors influencing estuarine phytoplankton production. Pages 69-90 in V. S. Kennedy, editor. Estuarine comparisons. Academic Press, New York, New York, USA.

Brenchley, W., and K. Warington. 1958. The Park Grass Plots at Rothamsted 1856-1949. (Reprinted 1969.) Rothamsted Experimental Station, Harpenden, England.

Burkholder, J. M., E. J. Noga, C. H. Hobbs, and H. B. Glas- 
gow. 1992. New "phantom" dinoflagellate is the causative agent of major estuarine fishkills. Nature 358:407-410.

Bytnerowicz, A., and M. E. Fenn. 1996. Nitrogen deposition in California forests: a review. Environmental Pollution 92: 127-146.

Carpenter, E. J., and D. G. Capone. 1983. Nitrogen fixation by marine Oscillatoria (Trichodesmium) in the world's oceans. Pages 65-103 in E. J. Carpenter, and D. G. Capone, editors. Nitrogen in the marine environment. Academic Press, New York, New York, USA.

Carpenter, E. J., and K. Romans. 1991. Major role of the cyanobacterium Trichodesmium in nutrient cycling in the North Atlantic Ocean. Science 254:1356-1358.

Chameides, W. L., P. S. Kasibhatla, J. Yienger, and H. Levy II. 1994. The growth of continental-scale metro-agro-plexes, regional ozone pollution, and world food production. Science 264:74-77.

Cole, J. J., B. L. Peierls, N. F. Caraco, and M. L. Pace. 1993. Nitrogen loadings of rivers as a human-driven process. Pages 141-157 in M. J. McDonnell and S. T. A. Pickett, editors. Humans as components of ecosystems: the ecology of subtle human effects and populated areas. Springer-Verlag, New York, New York, USA.

Cornell, S., A. Rendell, and T. Jickells. 1995. Atmospheric inputs of dissolved organic nitrogen to the oceans. Nature 376: $243-46$.

Cosper, E. M., W. C. Dennison, E. J. Carpenter, V. M. Bricelj, J. G. Mitchell, S. H. Kuenstner, D. C. Colflesh, and M. Dewey. 1987. Recurrent and persistent "brown tide" blooms perturb coastal marine ecosystem. Estuaries 10: 284-290.

Cronan, C. S., and D. F. Grigal. 1995. Use of calcium/aluminum ratios as indicators of stress in forest ecosystems. Journal of Environmental Quality 24:209-226.

Crutzen, P. J., and D. H. Ehhalt. 1977. Effects of nitrogen fertilizers and combustion on the stratospheric ozone layer. Ambio 6:112-117.

Davidson, E. A. 1991. Fluxes of nitrous oxide and nitric oxide from terrestrial ecosystems. Pages 219-235 in J. Rogers, and W. B. Whitman, editors. Microbial production and consumption of greenhouse gases. American Society for Microbiology, Washington, D.C., USA.

D’Elia, C. F., J. G. Sanders, and W. R. Boynton. 1986. Nutrient enrichment studies in a coastal plain estuary: phytoplankton growth in large-scale, continuous cultures. Canadian Journal of Fisheries and Aquatic Sciences 43:397406.

Delmas, R., D. Serça, and C. Jambert. In press. 1997. Global inventory of $\mathrm{NO}_{\mathrm{x}}$ sources. Nutrient Cycling in AgroEcosystems.

Delwiche, C. C. 1970. The nitrogen cycle. Scientific American 223: $137-146$.

Denmead, O. T. 1990. An ammonia budget for Australia. Australian Journal of Soil Research 28:887-900.

DoE [Department of Environment, UK]. 1994. Impacts of nitrogen deposition in terrestrial ecosystems. Technical Policy Branch, Air Quality Division, Department of Environment London, England

Driscoll, C. T., B. J. Wyskowski, C. C. Cosentini, and M. E. Smith. 1987. Processes regulating temporal and longitudinal chemistry of a low-order woodland stream in the Adirondack region of New York. Biogeochemistry 3:225242.

Durka, W., E-D. Schulze, G. Gebauer, and S. Voerkelius. 1994. Effects of forest decline on uptake and leaching of deposited nitrate determined from ${ }^{15} \mathrm{~N}$ and ${ }^{18} \mathrm{O}$ measurements. Nature 372:765-767.

Eichner, M. J. 1990. Nitrous oxide emissions from fertilized soils: summary of the available data. Journal of Environmental Quality 19:272-280.
Emmett, B. A., A. Brittain, S. Hughes, J. Gorres, V. Kennedy, D. Norris, R. Rafarel, B. Reynolds and P. A. Stevens. 1995. Nitrogen additions $\left(\mathrm{NaNO}_{3}\right.$ and $\left.\mathrm{NH}_{4} \mathrm{NO}_{3}\right)$ at Aber forest, Wales. I. response of throughfall and soil water chemistry. Forest Ecology and Management 71:45-60.

FAO [Food and Agriculture Organization of The United Nations]. 1993. Food and agriculture production yearbook 1992. Statistical Series 112. FAO, Rome, Italy.

Fenn, L. B., and L. R. Hossner. 1985. Ammonia volatilization from ammonia or ammonium-forming nitrogen fertilizers. Pages 123-169 in Advances in soil science. SpringerVerlag, New York, New York, USA.

Fisher, D. C., and M. Oppenheimer. 1991. Atmospheric nitrogen deposition and the Chesapeake Bay estuary. Ambio 20:102-108

Galloway, J. N., W. C. Keene, and G. E. Likens. 1996. Processes controlling the composition of precipitation at a remote southern hemispheric location: Torres del Paine National Park, Chile. Journal of Geophysical Research 101: 6883-6897.

Galloway, J. N., H. Levy II, and P. S. Kasibhatla. 1994. Year 2020: consequences of population growth and development on the deposition of oxidized nitrogen. Ambio 23:120-123.

Galloway, J. N., G. E. Likens, W. C. Keene, and J. M. Miller. 1982. The composition of precipitation in remote areas of the world. Journal of Geophysical Research 87:8771-8786.

Galloway, J. N., W. H. Schlesinger, H. Levy II, A. Michaels, and J. L. Schnoor. 1995. Nitrogen fixation: atmospheric enhancement-environmental response. Global Biogeochemical Cycles 9:235-252.

Grennfelt, P., and H. Hultberg. 1986. Effects of nitrogen deposition on the acidification of terrestrial and aquatic ecosystems. Water, Air, and Soil Pollution 30:945-963.

Hansson, S., and L. G. Rudstam. 1990. Eutrophication and Baltic fish communities. Ambio 19:123-125.

Hedin, L. O., J. J. Armesto, and A. H. Johnson. 1995. Patterns of nutrient loss from unpolluted, old-growth temperate forests: evaluation of biogeochemical theory. Ecology 76:493-509.

Henriksen, A., and D. F. Brakke. 1988. Increasing contributions of nitrogen to the acidity of surface waters in Norway. Water, Air, and Soil Pollution 42:183-201.

Howarth, R. W. 1988. Nutrient limitation of net primary production in marine ecosystems. Annual Review of Ecology and Systematics 19:89-110.

. 1991. Comparative responses of aquatic ecosystems to toxic chemical stress. Pages 161-195 in J. J. Cole, S. Findlay, and G. Lovett, editors. Comparataive analysis of ecosystems: patterns, mechanisms, and theories. SpringerVerlag, New York, New York, USA.

Howarth, R. W., G. Billen, D. Swaney, A. Townsend, N. Jaworski, K. Lajtha, J. A. Downing, R. Elmgren, N. Caraco, T. Jordan, F. Berendse, J. Freney, V. Kudeyarov, P. Murdoch, and Zhu Zhao-liang. 1996. Regional nitrogen budgets and riverine $\mathrm{N} \& \mathrm{P}$ fluxes for the drainages to the North Atlantic Ocean: Natural and human influences. Biogeochemistry 35:181-226.

Howarth, R. W., H. Jensen, R. Marino, and H. Postma. 1995. Transport and processing of phosphorus in near-shore and oceanic waters. Pages 323-345 in H. Tiessen, editor. Phosphorus in the global environment: transfers, cycles, and management. John Wiley \& Sons, Chichester, England.

Hudson, R. J., S. A. Gherini, and R. A. Goldstein. 1994. Modelling the global carbon cycle: nitrogen fertilization of the terrestrial biosphere and the "missing" $\mathrm{CO}_{2}$ sink. Global Biogeochemical Cycles 8:307-333.

Huenneke, L. F., S. P. Hamburg, R. Koide, H. A. Mooney, and P. M. Vitousek. 1990. Effects of soil resources on plant invasion and community structure in California serpentine grassland. Ecology 71:478-491. 
Hunt, H. W., E. R. Ingham, D. C. Coleman, E. T. Elliott, and C. P. P. Reid. 1988. Nitrogen limitation of production and decomposition in prairie, mountain meadow, and pine forest. Ecology 69:1009-1016.

Irving, P. M., editor. 1990. Acidic deposition: state of science and technology. Volume II. Aquatic processes and effects. U.S. National Atmospheric Precipitation Program, Washington, D.C., USA.

Jacob, D. J., and S. C. Wofsy. 1990. Budgets of reactive nitrogen, hydrocarbons, and ozone over the Amazon forest during the wet season. Journal of Geophysical Research 95: $16,737-16,754$.

Jansson, M., R. Andersson, H. Berggren, and L. Leonardson. 1994. Wetlands and lakes as nitrogen traps. Ambio 23: 320-325.

Johnson, D. W., M. S. Cresser, S. I. Nilsson, J. Turner, B. Ulrich, D. Binkley, and D. W. Cole. 1991. Soil changes in forest ecosystems: evidence for and probable causes. Pages 81-116 in F. T. Last and R. Watling, editors. Acidic deposition: its nature and impacts. Proceedings of the Royal Society of Edinburgh, Volume 97B.

Jordan, T. E., and D. E. Weller. 1996. Human contributions to terrestrial nitrogen flux. BioScience 46:655-664.

Justic, N., N. N. Rabalais, R. E. Turner, and Q. Dortch. 1995. Changes in nutrient structure of river-dominated coastal waters: stoichiometric nutrient balance and its consequences. Estuarine, Coastal and Shelf Science 40:339-356.

Kahl, J. S., S. A. Norton, I. J. Fernandez, K. J. Nadelhoffer, C. T. Driscoll, and J. D. Aber. 1993. Experimental inducement of nitrogen saturation at the watershed scale. Environmental Science and Technology 27:565-568.

Kates, R. W., B. L. Turner, and W. C. Clark. 1990. The great transformation. Pages 1-17 in B. L. Turner, W. C. Clark, R. W. Kates, J. F. Richards, J. T. Mathews, and W. B. Meyer, editors. The Earth as transformed by human action. Cambridge University Press, Cambridge, England.

Keeling, R. F., S. C. Piper, and M. Heimann. 1996. Global and hemispheric $\mathrm{CO}_{2}$ sinks deduced from changes in atmospheric $\mathrm{O}_{2}$ concentration. Nature 381:218-221.

Knap, A., T. Jickells, A. Pszenny, and J. Galloway. 1986. Significance of atmospheric-derived fixed nitrogen on productivity of the Sargasso Sea. Nature 320:158.

Larsson, U., R. Elmgren, and F. Wulff. 1985. Eutrophication and the Baltic Sea: causes and consequences. Ambio 14:914

Lawes, J., and J. Gilbert. 1880. Agricultural, botanical and chemical results of experiments on the mixed herbage of permanent grassland, conducted for many years in succession on the same land. I. Philosophical Transactions of the Royal Society of London B 171:189-514.

Lee, D. H. K. 1970. Nitrates, nitrites, and methemoglobinemia. Environmental Research 3:484-511.

Lein, A. Y., and M. V. Ivanov. 1992. Interaction of carbon, sulfur, and oxygen cycles in continental and marginal seas. Pages 189-213 in R. W. Howarth, J. W. B. Stewart, and M. V. Ivanov, editors. Sulphur cycling on the continents: wetlands, terrestrial ecosystems, and associated water bodies. John Wiley \& Sons, Chichester, England.

Leonardson, L. 1994. Wetlands as nitrogen sinks: Swedish and international experience. Naturvardsverket, Gotab, Stockholm, Sweden.

Levy, H., II, P. S. Kasibhatla, W. J. Moxim, and J. A. Logan. 1991. The global impact of biomass burning on tropospheric reactive nitrogen. Pages 263-269 in J. Levine, editor. Global biomass burning. MIT Press, Cambridge, Massachusetts, USA.

Likens, G. E., F. H. Bormann, N. M. Johnson, D. W. Fisher, and R. S. Pierce. 1970. Effects of forest cutting and herbicide treatment on nutrient budgets in the Hubbard Brook Watershed ecosystem. Ecological Monographs 40:23-47.
Likens, G. E., C. T. Driscoll, and D. C. Buso. 1996. Longterm effects of acid rain: response and recovery of a forest ecosystem. Science 272:244-246.

Likens, G. E., W. C. Keene, J. M. Miller, and J. N. Galloway. 1987. Chemistry of precipitation from a remote, terrestrial site in Australia. Journal of Geophysical Research 92: 13,299-13,314.

Lobert, J. M., D. H. Scharffe, W. M. Hao, and P. J. Crutzen. 1990. Importance of biomass burning in the atmospheric budget of nitrogen-containing trace gases. Nature 346:552554.

Logan, J. A. 1985. Tropospheric ozone: seasonal behavior, trends, and anthropogenic influence. Journal of Geophysical Research 90:10,463-10,482.

Magill, A. H., J. D. Aber, J. J. Hendricks, R. D. Bowden, J. M. Melillo, and P. Steudler. 1997. Biogeochemical response of forest ecosystems to simulated chronic nitrogen deposition. Ecological Applications 7:402-415.

Matthews, E. 1994. Nitrogenous fertilizers: global distribution of consumption and associated emissions of nitrous oxide and ammonia. Global Biogeochemical Cycles 8:411-439.

Matson, P. A., C. R. Billow, S. J. Hall, and J. Zachariassen. 1996. Fertilization practices and soil variations control nitrogen oxide emissions from tropical sugar cane. Journal of Geophysical Research 101:18,533-18,545.

Mayewski, P. A., W. B. Lyons, M. J. Spencer, M. Twickler, W. Dansgaard, B. Koci, C. I. Davidson, and R. E. Honrath. 1986. Sulfate and nitrate concentrations from a south Greenland ice core. Science 232:975-977.

McNulty, S. G., and J. D. Aber. 1993. Effects of chronic nitrogen additions on nitrogen cycling in a high-elevation spruce-fir stand. Canadian Journal of Forest Research 23: $1252-1263$.

Michaels, A. F., D. Olson, J. Sarmiento, J. Ammermann, K. Fanning, R. Jahnke, A. H. Knap, F. Lipschult, and J. Prospero. 1996. Inputs, losses, and transformations of nitrogen and phosphorus in the pelagic north Atlantic Ocean. Biogeochemistry 35:181-226.

Moody, D. W. 1990. Groundwater contamination in the United States. Journal of Soil and Water Conservation 45:170-179.

Murdoch, P. S., and J. L. Stoddard. 1991. The role of nitrate in stream acidification in the Catskill Mountains, New York. Water Resources Research 28:2707-2720.

Nilsson, J., and P. Grennfelt. 1988. Critical loads for sulphur and nitrogen. Miljorapport, Nordic Council of Ministries, Stockholm, Sweden.

Nixon, S. W. 1995. Coastal marine eutrophication: a definition, social causes, and future concerns. Ophelia 41:199-219.

Nixon, S. W., J. W. Ammerman, L. P. Atkinson, V. M. Berounsky, G. Billen, W. C. Boicourt, W. R. Boyton, T. M. Church, D. M. Ditoro, R. Elmgren, J. H. Garber, A. E. Giblin, R. A. Jahnke, N. P. J. Owens, M. E. Q. Pilson, and S. P. Seitzinger. 1996. The fate of nitrogen and phosphorus at the land-sea margin of the North Atlantic Ocean. Biogeochemistry 35:141-180.

NRC [National Research Council Committee on Wastewater Management for Coastal Urban Areas, Water Science and Technology Board]. 1993. Managing wastewater in coastal urban areas. National Research Council, Washington, D.C., USA.

NRC [National Research Council Committee on Priorities for Ecosystem Research in the Coastal Zone, Ocean Sciences Board]. 1994. Priorities for coastal ecosystem science. National Research Council, Washington, D.C., USA.

Officer, C. B., R. B. Biggs, J. Taft., L. E. Cronin, M. A. Tyler, and W. R. Boynton. 1984. Chesapeake Bay anoxia: origin, development, and significance. Science 223:22-27.

Paces, T. 1982. Natural and anthropogenic flux of major elements from central Europe. Ambio 11:206-208.

Parker, C. A., and J. E. O'Reilly. 1991. Oxygen depletion in 
Long Island Sound: a historical perspective. Estuaries 14: 248-264.

Paul, E. A., and F. E. Clark. 1989. Soil microbiology and biochemistry. Academic Press, San Diego, California, USA.

Peierls, B., N. Caraco, M. Pace, and J. J. Cole. 1991. Human influence on river nitrogen. Nature 350:386-387.

Peterson, B. J., and J. M. Melillo. 1985. The potential storage of carbon caused by eutrophication of the biosphere. Tellus 37B: $117-127$.

Posch, M., P. A. M. de Smet, J.-P. Hettelingh, and R. J. Downing, editors. 1995. Calculation and mapping of critical thresholds in Europe. Status report 1995. RIVM report 259101004. National Institute of Public Health and the Environment, Bilthoven, The Netherlands.

Prather, M., R. Derwent, D. Ehhalt, P. Fraser, E. Sahueza, and X. Zhou. 1995. Other trace gases and atmospheric chemistry. Pages 77-126 in J. T. Houghton, L. G. Meira Filho, J. Bruce, H. Lee, B. A. Callander, E. Haites, N. Harris, and K. Maskell, editors. Climate change 1994: radiative forcing of climate change. Cambridge University Press, Cambridge, England.

Prinn, R., D. Cunnold, R. Rasmussen, P. Simmonds, F. Alyca, A. Crawford, P. Fraser, and R. Rosen. 1990. Atmospheric emissions and trends of nitrous oxide deduced from 10 years of ALE-GAGE data. Journal of Geophysical Research 95: $18,369-18,385$.

Rasmussen, L., T. Brydges, and P. Mathy. 1993. Experimental manipulations of biota and biogeochemical cycling in ecosystems. Report 4, Ecosystem Research Report Series. Commission of the European Communities, Brussels, Belgium.

Reich, P. B., and R. B. Amundson. 1985. Ambient levels of ozone reduce net photosynthesis in tree and crop species. Science 230:566-570.

Rosenberg, R. 1985. Eutrophication-The future marine coastal nuisance. Marine Pollution Bulletin 16:227-231.

Rudd, J. W. M., C. A. Kelly, D. W. Schindler, and M. A. Turner 1988. Disruption of the nitrogen cycle in acidified lakes. Science 240:1515-1517.

Rudd, J. W. M., C. A. Kelly, D. W. Schindler, and M. A. Turner 1990. A comparison of the acidification efficiencies of nitric and sulfuric acids by two whole-lake addition experiments. Limnology and Oceanography 35:663-679.

Schaefer, D. A., C. T. Driscoll Jr., R. van Dreason, and C. P Yatsko. 1990. The episodic acidification of Adirondack lakes during snowmelt. Water Resources Research 26:16391647

Schimel, D. S., I. G. Enting, M. Heimann, T. M. L. Wigley, D. Raynard, D. Alves, and U. Siegenthaler. 1995. $\mathrm{CO}_{2}$ and the carbon cycle. Pages 39-71 in J. T. Houghton, L. G. Meira Filho, J. Bruce, H. Lee, B. A. Callander, E. Haites, N. Harris, and K. Maskell, editors. Climate change 1994: radiative forcing of climate change. Cambridge University Press, Cambridge, England.

Schindler, D. W. 1977. Evolution of phosphorus limitation in lakes. Science 195:260-262.

- 1990. Experimental perturbations of whole lakes as tests of hypotheses concerning ecosystem structure and function. Oikos 57:25-41.

1994. Changes caused by acidification to the biodiversity, productivity and biogeochemical cycles of lakes. Pages 153-164 in C. E. W. Steinberg and R. W. Wright, editors. Acidification of freshwater ecosystems. Implications for the future. John Wiley \& Sons, Chichester, England.

Schindler, D. W., and S. E. Bayley. 1993. The biosphere as an increasing sink for atmospheric carbon:estimates from increasing nitrogen deposition. Global Biogeochemical Cycles 7:717-734.

Schindler, D. W., T. M. Frost, K. H. Mills, P. S. S. Chang, I. J. Davis, F. L. Findlay, O. F. Malley, J. A. Shearer, M. A. Turner, P. J. Garrison, C. J. Watras, K. Webster, J. M. Gunn,
P. L. Brezonik, and W. A. Swenson. 1991. Freshwater acidification, reversibility and recovery: comparisons of experimental and atmospherical acidified lakes. Proceedings of the Royal Society of Edinburgh 878:193-226.

Schindler, D. W., R. W. Newbury, K. G. Beaty, J. Prokopowich, T. Ruszczynski, and J. A. Dalton. 1980. Effects of a windstorm and forest fire on chemical losses from forested watersheds and on the quality of receiving streams. Canadian Journal of Fisheries and Aquatic Sciences 37:328-334.

Schindler, D. W., M. A. Turner, and R. H. Hesslein. 1985. Acidification and alkalinization of lakes by experimental addition of nitrogen compounds. Biogeochemistry 1:117-133.

Schlesinger, W. H. 1991. Biogeochemistry: an analysis of global change. Academic Press, San Diego, California, USA.

Schlesinger, W. H., and A. E. Hartley. 1992. A global budget for atmospheric $\mathrm{NH}_{3}$. Biogeochemistry 15:191-211.

Schulze, E. D. 1989. Air pollution and forest decline in a spruce (Picea abies) forest. Science 244:776-783.

Schuurkes, J. A. A. R., and R. Mosello. 1988. The role of external ammonium inputs in freshwater acidification. Schweizerische Zeitschrift für Hydrologie 50:71-86.

Shortle, W. C., and K. T. Smith. 1988. Aluminum-induced calcium deficiency syndrome in declining red spruce. Science 240:239-240.

Silvertown, J. W. 1980. The dynamics of a grassland ecosystem: botanical equilibrium in the Park Grass experiment. Journal of Applied Ecology 17:491-504.

Smayda, T. J. 1989. Primary production and the global epidemic of phytoplankton blooms in the sea: a linkage? Pages 29-40 in E. M. Cosper, E. J. Carpenter, and V. M. Bricelj, editors. Novel phytoplankton blooms: causes and impacts of recurrent brown tides and other unusual blooms. SpringerVerlag, Berlin, Germany.

Smil, V. 1990. Nitrogen and phosphorus. Pages 423-436 in B. L. Turner II, W. C. Clark, R. W. Kates, J. F. Richards, J. T. Mathews, and W. B. Meyer, editors. The Earth as transformed by human action. Cambridge University Press, Cambridge, England.

- 1991. Population growth and nitrogen: an exploration of a critical existential link. Population and Development Review 17:569-601.

Soderlund, R., and T. H. Rosswall. 1982. The nitrogen cycles. Pages 62-81 in O. Hutzinger, editor. Handbook of enviromental chemistry. Springer-Verlag, Berlin, Germany.

Stoddard, J. L. 1994. Long-term changes in watershed retention of nitrogen: its causes and aquatic consequences. Pages 223-284 in L. A. Baker, editor. Environmental chemistry of lakes and reservoirs. American Chemical Society, Washington, D.C., USA.

Tamm, C. O. 1991. Nitrogen in terrestrial ecosystems. Springer-Verlag, Berlin, Germany.

Thurston, J. 1969. The effect of liming and fertilizers on the botanical composition of permanent grassland, and on the yield of hay. Pages 3-10 in I. Rorison, editor. Ecological aspects of the mineral nutrition of plants. Blackwell Scientific, Oxford, England.

Tilman, D. 1987. Secondary succession and the pattern of plant dominance along experimental nitrogen gradients. Ecological Monographs 57:189-214.

1996. Biodiversity: population versus ecosystem stability. Ecology 77:350-363.

Tilman, D., and J. A. Downing. 1994. Biodiversity and stability in grasslands. Nature 367:363-365.

Townsend, A. R., B. H. Braswell, E. A. Holland, and J. E. Penner. 1996. Spatial and temporal patterns in terrestrial carbon storage due to deposition of fossil fuel nitrogen. Ecological Applications 6:806-814.

Turner, R. E., and N. N. Rabalais. 1991. Changes in Mississippi River water quality this century. BioScience 41:140147. 
Van Miegroet, H. 1992. The relative importance of sulfur and nitrogen compounds in the acidification of fresh water. Pages 33-50 in C. E. W. Steinberg, and R. F. Wright, editors. Acidification of freshwater ecosystems: implications for the future. John Wiley \& Sons, Chichester, England.

Van Miegrot, H., D. W. Cole, and N. W. Foster. 1992. Nitrogen distribution and cycling. Pages 178-213 in D. W. Johnson and S. E. Lindberg, editors. Atmospheric distribution and forest nutrient cycling. Springer-Verlag, New York, New York, USA.

Vitousek, P. M., and R. W. Howarth. 1991. Nitrogen limitation on land and in the sea: How can it occur? Biogeochemistry 13:87-115.
Vitousek, P. M., and P. A. Matson. 1993. Agriculture, the global nitrogen cycle, and trace gas flux. Pages 193-208 in R. S. Oremland, editor. The biogeochemistry of global change: radiative trace gases. Chapman \& Hall, New York, New York, USA.

Williams, E. J., G. L. Hutchinson, and F. C. Fehsenfeld. 1992. $\mathrm{NO}_{\mathrm{x}}$ and $\mathrm{N}_{2} \mathrm{O}$ emissions from soil. Global Biogeochemical Cycles 6:351-388.

Wright, R. F., and N. van Breeman. 1995. The NITREX project: an introduction. Forest Ecology and Management 71: $1-6$.

Yienger, J. J., and H. Levy II. 1994. Empirical model of global soil biogenic $\mathrm{NO}_{\mathrm{x}}$ emissions. Journal of Geophysical Research 100: 11 447-11 464 . 